\title{
Tenacibaculum aiptasiae sp. nov., isolated from a sea anemone Aiptasia pulchella
}

Correspondence Wen-Ming Chen p62365@ms28.hinet.net

\author{
Jih-Terng Wang, ${ }^{1}$ Yi-Ju Chou, ${ }^{2}$ Jui-Hsing Chou, ${ }^{3}$ Chaolun Allen Chen ${ }^{4}$ \\ and Wen-Ming Chen ${ }^{2}$
}

\author{
${ }^{1}$ Department of Biotechnology, Tajen University, Pingtung 907, Taiwan \\ ${ }^{2}$ Laboratory of Microbiology, Department of Seafood Science, National Kaohsiung Marine \\ University, 142 Hai-Chuan Rd, Nan-Tzu, Kaohsiung City 811, Taiwan \\ ${ }^{3}$ Department of Soil Environmental Science, College of Agriculture and Natural Resources, \\ National Chung Hsing University, Taichung, Taiwan \\ ${ }^{4}$ Research Center for Biodiversity, Academia Sinica, Taipei 115, Taiwan
}

\begin{abstract}
A novel bacterial strain, designated $\mathrm{a} 4^{\top}$, isolated from a sea anemone (Aiptasia pulchella) in Taiwan, was characterized using a polyphasic taxonomic approach. Strain $a 4^{\top}$ was aerobic, Gram-negative, pale-yellow-pigmented and rod-shaped. It grew optimally at $30-35{ }^{\circ} \mathrm{C}$, in the presence of $3-4 \%(\mathrm{w} / \mathrm{v}) \mathrm{NaCl}$ and at $\mathrm{pH}$ 8.0. Phylogenetic analyses based on 16S rRNA gene sequences showed that the strain belonged to the genus Tenacibaculum (family

Flavobacteriaceae, phylum Bacteroidetes). The closest neighbours were Tenacibaculum lutimaris TF-26 ${ }^{\top}$ (97.6 \% similarity) and Tenacibaculum aestuarii SMK $-4^{\top}$ ( $97.7 \%$ similarity). The novel isolate could be distinguished from all Tenacibaculum species by several phenotypic characteristics. The major fatty acids were summed feature 3 (comprising $\mathrm{C}_{16: 1} \omega 7 \mathrm{c}$ and/or iso- $\left.\mathrm{C}_{15: 0} 2-\mathrm{OH}, 19.6 \%\right)$, iso- $\mathrm{C}_{15: 0}(12.9 \%)$, iso- $\mathrm{C}_{16: 0} 3-\mathrm{OH}(10.2 \%)$, iso- $\mathrm{C}_{17: 0} 3-\mathrm{OH}(9.9 \%)$ and iso- $\mathrm{C}_{15: 1}(9.5 \%)$. The DNA G+C content was 35.0 mol\%. Hence, genotypic and phenotypic data demonstrate that strain $a 4^{\top}$ should be classified as a representative of a novel species in the genus Tenacibaculum, for which the name Tenacibaculum aiptasiae sp. nov. is proposed. The type strain is $a 4^{\top}\left(=B C R C 17655^{\top}=\right.$ LMG $\left.24004^{\top}\right)$.
\end{abstract}

The genus Tenacibaculum (Suzuki et al., 2001) is a member of the family Flavobacteriaceae (Reichenbach, 1992a, b; Bernardet et al., 1996, 2002; Bernardet \& Nakagawa, 2006) and encompasses Gram-negative, non-spore-forming, yellow-pigmented, straight rods with a DNA G $+\mathrm{C}$ content of 30.0-35.2 mol\% (Suzuki et al., 2001; Frette et al., 2004; Yoon et al., 2005; Choi et al., 2006; Sheu et al., 2007). It currently contains nine species isolated from different marine sources, including Tenacibaculum maritimum, $T$. ovolyticum, T. mesophilum, T. amylolyticum, T. skagerrakense, T. lutimaris, T. litoreum, T. aestuarii and T. litopenaei (Wakabayashi et al., 1986; Hansen et al., 1992; Suzuki et al., 2001; Frette et al., 2004; Yoon et al., 2005; Choi et al., 2006; Jung et al., 2006; Sheu et al., 2007).

The GenBank/EMBL/DDBJ accession number for the $16 \mathrm{~S}$ rRNA gene sequence of Tenacibaculum aiptasiae ${ }^{2} 4^{\top}$ is EF416572.

A comparison of the fatty acid composition of strain $a 4^{\top}$ and related type strains, the MicroPlate GN2 profile of strain $\mathrm{a}^{\top}{ }^{\top}$ and a $16 \mathrm{~S}$ rRNA gene sequence-based phylogenetic tree including two novel Tenacibaculum species, details of which were published after submission of this paper, are available as supplementary material with the online version of this paper.
Aiptasia pulchella is a sea anemone that is widely distributed in the tropical and subtropical Pacific Ocean. It is easily cultured in the laboratory and commonly used as a model animal for studies of the Symbiodiniumcnidarian symbiosis (Wang \& Douglas, 1997, 1998, 1999). However, it occasionally becomes unhealthy for unknown reasons when maintained in a closed system. In this study, the taxonomic position of a novel organism, designated strain $\mathrm{a} 4^{\mathrm{T}}$, which was isolated from a diseased sea anemone, is described.

In order to isolate micro-organisms from a sea anemone maintained in an aquarium in Pingtung, Taiwan, the animal was surface-sterilized with $75 \%$ ethanol for $30 \mathrm{~s}$, rinsed six times in sterile artificial seawater $(\mathrm{NaCl}, 24 \mathrm{~g}$; $\mathrm{MgCl}_{2}, 5.1 \mathrm{~g} ; \mathrm{Na}_{2} \mathrm{SO}_{4}, 4 \mathrm{~g} ; \mathrm{CaCl}_{2}, 1.1 \mathrm{~g} ; \mathrm{KCl}, 0.7 \mathrm{~g}$; $\mathrm{NaHCO}_{3}, \quad 0.2$ g; KBr, 0.1 g; $\mathrm{H}_{3} \mathrm{BO}_{3}, 0.027 \mathrm{~g} ; \mathrm{SrCl}_{2}$, $0.024 \mathrm{~g} ; \mathrm{NaF}, 0.003 \mathrm{~g}$; distilled water, $1 \mathrm{l}$; Lyman \& Fleming, 1940), crushed and streaked on marine 2216 agar (MA; BD Difco) plates incubated at $25{ }^{\circ} \mathrm{C}$. After primary isolation, strain $\mathrm{a} 4^{\mathrm{T}}$ was subcultivated on MA or in marine 2216 broth (MB; BD Difco). The strain was preserved as a suspension in $20 \%(\mathrm{v} / \mathrm{v})$ glycerol $\mathrm{MB}$ or by lyophilization 
in $20 \%(\mathrm{w} / \mathrm{v})$ skimmed milk MB. The organism was subjected to a polyphasic taxonomic study.

The morphology of bacterial cells was observed in an $\mathrm{MB}$ culture grown at $25{ }^{\circ} \mathrm{C}$ for $6 \mathrm{~h}$ (lag growth phase), $18 \mathrm{~h}$ (exponential phase) and $36 \mathrm{~h}$ (stationary phase) under a phase-contrast microscope (Leica DM 2000). Gliding motility was tested as described by Bowman (2000) and Bernardet et al. (2002) using an MB culture grown for 24 and $48 \mathrm{~h}$ at $25{ }^{\circ} \mathrm{C}$. Flagellar staining was performed using the Spot Test flagella stain (BD Difco). The Gram reaction was performed using the Gram stain set (BD Difco) and the Ryu non-staining KOH method (Powers, 1995). Accumulation of poly- $\beta$-hydroxybutyrate granules was observed by light microscopy after staining cells with Sudan black. Colony morphology was examined using a stereoscopic microscope (Nikon SMZ 800). Cellular pigments were extracted with acetone/methanol $(7: 2$, $\mathrm{v} / \mathrm{v})$, from cultures grown on MA and absorption spectra were determined with a scanning UV/visible spectrophotometer (Helios Delta; Thermo Fisher Scientific). The presence of flexirubin-type pigments was investigated as described by Reichenbach (1992a) and Bernardet et al. (2002). The optimum $\mathrm{pH}$ range for growth was examined in $\mathrm{MB}$ using appropriate biological buffers such as glycine/ $\mathrm{HCl}$, citrate $/ \mathrm{Na}_{2} \mathrm{HPO}_{4}$, phosphate buffer and glycine/ $\mathrm{NaOH}$ for adjusting the $\mathrm{pH}$ to $3.0-4.0,4.0-8.0,6.0-8.0$ and $9.0-11.0$ (at $1.0 \mathrm{pH}$ unit intervals), respectively. The $\mathrm{pH}$ values were adjusted prior to sterilization and poststerilization controls revealed that only minor changes in $\mathrm{pH}$ had occurred. The $\mathrm{NaCl}$ requirement was determined using nutrient broth (BD Difco) containing $0,0.5$ and 1.0$10.0 \%(\mathrm{w} / \mathrm{v}) \mathrm{NaCl}$ (at $1.0 \%$ intervals). The temperature range for growth was examined at $4,8,10,15,20,25,30$, 35,40 and $42{ }^{\circ} \mathrm{C}$ in $\mathrm{MB}$ adjusted to $\mathrm{pH} 7.0$ using an orbital water-bath shaker (125 r.p.m.). Growth rate was determined by measuring the turbidity $\left(\mathrm{OD}_{600}\right)$ of cultures grown at various $\mathrm{pH}, \mathrm{NaCl}$ concentrations and temperatures. Anaerobic growth was tested on MA using the Oxoid AnaeroGen system. Catalase, oxidase and DNase activities and hydrolysis of starch, casein, chitin, aesculin, gelatin and Tweens 20, 40, 60 and 80 were determined using standard methods (Gerhardt et al., 1994; MacFaddin, 2000; Chang et al., 2004). The commercially available API 20NE (bioMérieux), API ZYM (bioMérieux) and MicroPlate GN2 (Biolog) microtest systems were used, according to the manufacturers' instructions, to determine the biochemical properties, enzyme activities and carbohydrate utilization pattern of strain $\mathrm{a} 4^{\mathrm{T}}$. The API ZYM strip was read after $4 \mathrm{~h}$ incubation at $37^{\circ} \mathrm{C}$, whereas API 20NE and MicroPlate GN2 were read after $72 \mathrm{~h}$ at $25^{\circ} \mathrm{C}$. The three commercial systems were inoculated with a cell suspension in artificial seawater. Sensitivity of strain $\mathrm{a} 4^{\mathrm{T}}$ to different antibiotics was analysed by the diffusion method on MA. The following antibiotic discs (Oxoid) were used: ampicillin $(10 \mu \mathrm{g})$, chloramphenicol $(30 \mu \mathrm{g})$, gentamicin $(10 \mu \mathrm{g})$, kanamycin $(30 \mu \mathrm{g})$, nalidixic acid $(30 \mu \mathrm{g})$, novobiocin $(30 \mu \mathrm{g})$, rifampicin $(5 \mu \mathrm{g})$, penicillin $\mathrm{G}(10 \mathrm{U})$, streptomycin $(10 \mu \mathrm{g})$ and tetracycline $(30 \mu \mathrm{g})$. The effect of antibiotics on cell growth was assessed after 2 days incubation at $25{ }^{\circ} \mathrm{C}$ and susceptibility was scored based on the distance from the edge of the clear zone to the disc.

Extraction of genomic DNA, PCR amplification and sequencing of the 16S rRNA gene were carried out as described by Chen et al. (2001). Sequences were assembled by using the Fragment Assembly System program of the Wisconsin Package 8.1 (GCG, 1995). Multiple-sequence alignments of strain $\mathrm{a} 4^{\mathrm{T}}$ and its closest relatives were performed using BIOEDIT (Hall, 1999) and MEGA version 3.1 (Kumar et al., 2004). Phylogenetic trees were inferred using the maximum-parsimony (Kluge \& Farris, 1969) and neighbour-joining (Saitou \& Nei, 1987) tree-making algorithms. An evolutionary-distance matrix was generated for the neighbour-joining algorithm using the Jukes \& Cantor (1969) distance model and bootstrap analysis (1000 resamplings).

The nearly complete $16 \mathrm{~S}$ rRNA gene sequence (1434 nt) of strain $\mathrm{a} 4^{\mathrm{T}}$ was obtained. Its comparison with the sequences of representative members of genera in the family Flavobacteriaceae showed that this organism fell within the evolutionary radiation of the genus Tenacibaculum (Fig. 1). Sequence similarity calculations using the pairwise alignment obtained from the EzTaxon database (Chun et al., 2007) showed that strain $\mathrm{a} 4^{\mathrm{T}}$ shared the greatest degree of $16 \mathrm{~S}$ rRNA gene sequence similarity with $T$.

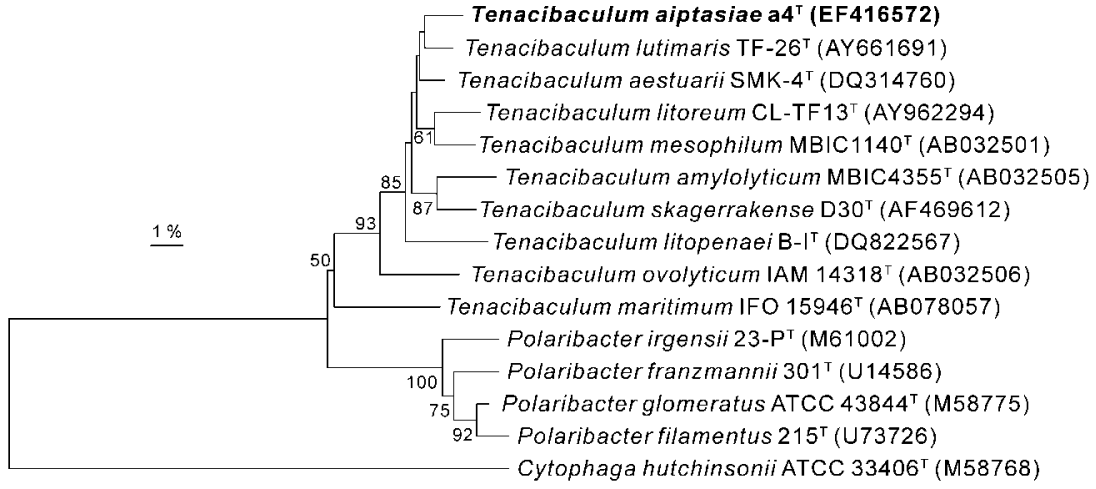

Fig. 1. Neighbour-joining phylogenetic tree based on 16S rRNA gene sequences of strain $\mathrm{a} 4^{\top}$, other Tenacibaculum species and related taxa. Sequences were retrieved from EMBL (accession numbers are given in parentheses). Numbers at nodes are bootstrap values (>50\%) based on 1000 resampled datasets. Cytophaga hutchinsonii ATCC $33406^{\top}$ was used as an outgroup. The maximum-parsimony tree showed a very similar topology (not shown). Bar, $1 \%$ sequence dissimilarity. 
Table 1. Phenotypic characteristics of strain $a 4^{\top}$ and other Tenacibaculum species

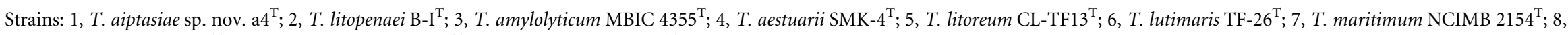

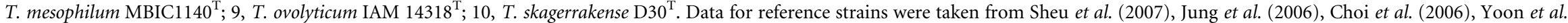


-, negative; W, weakly positive; NA, not available; NG, no growth with $\mathrm{NaCl}$ only.

\begin{tabular}{|c|c|c|c|c|c|c|c|c|c|c|}
\hline Characteristic & 1 & 2 & 3 & 4 & 5 & 6 & 7 & 8 & 9 & 10 \\
\hline Origin & $\begin{array}{l}\text { Sea anemones, } \\
\text { Taiwan }\end{array}$ & $\begin{array}{l}\text { Shrimp culture } \\
\text { pond, Taiwan }\end{array}$ & $\begin{array}{l}\text { Macroalgae, } \\
\text { Japan }\end{array}$ & $\begin{array}{l}\text { Tidal flat, } \\
\text { Korea }\end{array}$ & $\begin{array}{l}\text { Tidal flat, } \\
\text { Korea }\end{array}$ & $\begin{array}{c}\text { Tidal flat, } \quad \mathrm{I} \\
\text { Korea }\end{array}$ & $\begin{array}{c}\text { Diseased Red sea } \\
\text { bream, Japan }\end{array}$ & $\begin{array}{l}\text { Sponge and } \\
\text { macroalgae, Japan }\end{array}$ & $\begin{array}{l}\text { Halibut egg, } \\
\text { Norway }\end{array}$ & $\begin{array}{l}\text { Pelagic, } \\
\text { Denmark }\end{array}$ \\
\hline \multicolumn{11}{|l|}{ Colony morphology } \\
\hline Shape & $\begin{array}{l}\text { Circular, convex, } \\
\text { spreading edge }\end{array}$ & $\begin{array}{l}\text { Circular, convex, } \\
\text { spreading edge }\end{array}$ & $\begin{array}{c}\text { Circular, } \\
\text { spreading edge }\end{array}$ & $\begin{array}{l}\text { Irregular, } \\
\text { spreading edge }\end{array}$ & $\begin{array}{l}\text { Irregular, } \\
\text { spreading edge }\end{array}$ & $\begin{array}{l}\text { Irregular, } \\
\text { spreading edge }\end{array}$ & Uneven edge I & $\begin{array}{c}\text { Irregular, spreading } \\
\text { edge }\end{array}$ & Regular edge & $\begin{array}{l}\text { Circular, } \\
\text { convex, } \\
\text { spreading } \\
\text { edge }\end{array}$ \\
\hline $\begin{array}{l}\text { Diameter at } 5 \text { days } \\
(\mathrm{mm})\end{array}$ & $10-20$ & $5-20$ & $23-27$ & $5-10$ & $5-10$ & $10-20$ & $<5$ & $30-60$ & $\mathrm{NA}$ & $5-20$ \\
\hline Colour & Pale yellow & Yellow & Yellow & Pale yellow & Pale yellow & Pale yellow & Pale yellow & Yellow & Pale yellow & Bright yellow \\
\hline Cell size $(\mu \mathrm{m})$ & $0.4-0.6 \times 2-7$ & $0.3-0.5 \times 2-10$ & $0.4 \times 2-5$ & $0.3 \times 2-3.5$ & $0.3-0.5 \times 2-35$ & $0.5 \times 2-10$ & $0.5 \times 2-30$ & $0.5 \times 1.5-10$ & $0.5 \times 2-20$ & $0.5 \times 2-15$ \\
\hline $\begin{array}{l}\text { Spherical cells in } \\
\text { ageing broth } \\
\text { cultures }\end{array}$ & Very rare & Very rare & Very rare & $\mathrm{NA}$ & Very rare & Very rare & Frequent & Very rare & Absent & Frequent \\
\hline Gliding motility & + & + & + & + & + & + & + & + & + & - \\
\hline $\begin{array}{l}\text { Salinity tolerance } \\
(\mathrm{NaCl} ; \%)\end{array}$ & $1-10$ & $2-10$ & $3(w)$ & $<7$ & $3-5$ & $<8$ & NG & $1-7$ & NG & NG \\
\hline Growth at $\mathrm{pH} 5$ & - & + & - & - & - & + & - & - & - & - \\
\hline Nitrate reduction & - & - & $\mathrm{W}$ & - & + & - & + & - & + & + \\
\hline \multicolumn{11}{|l|}{ Hydrolysis of: } \\
\hline Chitin & - & + & - & $\mathrm{NA}$ & $\mathrm{NA}$ & $\mathrm{NA}$ & - & - & + & - \\
\hline Starch & + & + & + & - & + & - & - & - & - & + \\
\hline Gelatin & + & + & + & + & + & + & - & + & + & $\mathrm{NA}$ \\
\hline Tween 80 & + & - & + & + & + & - & + & + & + & - \\
\hline \multicolumn{11}{|l|}{$\begin{array}{l}\text { Carbon source } \\
\text { utilization }\end{array}$} \\
\hline Citrate & - & - & - & $\mathrm{NA}$ & - & $\mathrm{NA}$ & - & - & - & + \\
\hline L-Leucine & - & - & - & - & - & - & - & - & - & $\mathrm{W}$ \\
\hline L-Proline & - & + & + & - & + & - & - & + & - & + \\
\hline L-Glutamate & + & + & + & - & - & - & $\mathrm{W}$ & + & - & + \\
\hline L-Aspartate & + & - & - & - & - & - & - & + & - & + \\
\hline D-Glucose & - & + & $\mathrm{NA}$ & - & - & - & $\mathrm{NA}$ & $\mathrm{NA}$ & $\mathrm{NA}$ & + \\
\hline Sucrose & - & - & - & - & - & - & - & - & - & + \\
\hline $\begin{array}{l}\text { DNA G }+ \text { C content } \\
(\mathrm{mol} \%)\end{array}$ & 35.0 & 35.2 & 30.9 & 33.6 & 30 & 32.6 & 31.6 & 31.8 & 30.3 & 35.2 \\
\hline
\end{tabular}


lutimaris $\mathrm{TF}-26^{\mathrm{T}} \quad(97.6 \%)$ and $T$. aestuarii $\mathrm{SMK}-4^{\mathrm{T}}$ $(97.7 \%)$. Strain a $4^{\mathrm{T}}$ shared lower $16 \mathrm{~S}$ rRNA gene sequence similarities with the type strains of T. litoreum (96.9\%), T. mesophilum (96.7\%), T. skagerrakense (96.6\%), T. ovolyticum $(96.4 \%)$, T. amylolyticum (95.6\%), T. litopenaei $(95.5 \%)$ and T. maritimum (94.8\%). Similarity levels of strain $\mathrm{a} 4^{\mathrm{T}}$ with other bacterial species in the family Flavobacteriaceae were less than $94.5 \%$.

DNA-DNA hybridization experiments were performed with photobiotin-labelled probes using the fluorometric method of Ezaki et al. (1989). Hybridizations were conducted in $50 \%$ formamide at $50{ }^{\circ} \mathrm{C}$. Reciprocal reactions were also performed and all experiments were duplicated. Strain $a 4^{\mathrm{T}}$ shared only low levels of DNA relatedness with its closest phylogenetic neighbours $T$. lutimaris $\mathrm{TF}-26^{\mathrm{T}}(28 \pm 5 \%$; reciprocal, $21 \pm 6 \%)$ and $T$. aestuarii SMK- $4^{\mathrm{T}}(23 \pm 7 \%$; reciprocal, $19 \pm 2 \%$ ), clearly indicating that it represents a novel species in the genus Tenacibaculum.

Fatty acids were extracted from cells grown on MA for $48 \mathrm{~h}$ at $28{ }^{\circ} \mathrm{C}$ and prepared by the standard protocol of the Microbial Identification System (MIDI; Microbial ID) (Sasser, 1990). The fatty acid composition of strain $\mathrm{a} 4^{\mathrm{T}}$ was dominated by summed feature 3 (comprising $\mathrm{C}_{16: 1}$ $\omega 7 c$ and/or iso- $\left.\mathrm{C}_{15: 0} 2-\mathrm{OH} ; 19.6 \%\right)$, iso- $\mathrm{C}_{15: 0}(12.9 \%)$, iso- $\mathrm{C}_{16: 0} 3-\mathrm{OH}(10.2 \%)$, iso- $\mathrm{C}_{17: 0} 3-\mathrm{OH}(9.9 \%)$ and iso$\mathrm{C}_{15: 1}(9.5 \%)$. The detailed fatty acid composition of strain $\mathrm{a} 4{ }^{\mathrm{T}}$, available in Supplementary Table S1 in IJSEM Online, was in accordance with those of other Tenacibaculum species (Jung et al., 2006; Choi et al., 2006; Yoon et al., 2005; Sheu et al., 2007). Menaquinones were extracted and analysed by HPLC as described by Collins et al. (2000). The predominant quinone of strain $\mathrm{a} 4^{\mathrm{T}}$ was a menaquinone with six isoprenoid units (MK-6). The DNA G + C content of strain $\mathrm{a}^{\mathrm{T}}$, determined in triplicate as described by Mesbah et al. (1989), was $35.0 \pm 1.0 \mathrm{~mol} \%$, which is within the range reported previously for Tenacibaculum species (30.0-35.2 mol\%; Table 1).

Detailed results of the phenotypic study are provided in Table 1 and in the species description; MicroPlate GN2 data are available in Supplementary Table S2. Results indicated that strain $\mathrm{a} 4^{\mathrm{T}}$ could be distinguished from its phylogenetic relatives using a combination of phenotypic properties, especially nitrate reduction, hydrolysis of chitin, starch, gelatin and Tween 80 and utilization of various organic compounds.

Hence, genotypic and phenotypic data support the description of a novel species in the genus Tenacibaculum for strain $\mathrm{a} 4^{\mathrm{T}}$. The name Tenacibaculum aiptasiae sp. nov. is proposed for this taxon.

After submission of this manuscript, Piñeiro-Vidal et al. (2008) described two novel species of the genus Tenacibaculum. The 16S rRNA gene sequence similarity values of the sequence of strain $\mathrm{a} 4^{\mathrm{T}}$ to the type strains of these two species are $96.8 \%$ to Tenacibaculum discolor LL04 11.1.1 ${ }^{\mathrm{T}}$ and $96.6 \%$ to Tenacibaculum gallaicum
A37.1 $1^{\mathrm{T}}$. To evaluate the position of all known Tenacibaculum species, a new phylogenetic dendrogram based on 16S rRNA gene sequences was constructed (Supplementary Fig. S1); in this tree, strain $\mathrm{a} 4^{\mathrm{T}}, T$. discolor LL04 11.1.1 ${ }^{\mathrm{T}}$ and T. gallaicum A37. $1^{\mathrm{T}}$ form three distinct branches within the genus Tenacibaculum.

\section{Description of Tenacibaculum aiptasiae sp. nov.}

Tenacibaculum aiptasiae (aip.ta'si.ae. N.L. n. Aiptasia the scientific name of a genus of sea anemone; N.L. gen. n. aiptasiae isolated from a sea anemone belonging to the genus Aiptasia).

Cells are aerobic, Gram-negative, non-flagellated, non-sporeforming, straight rods $(0.4-0.6 \mu \mathrm{m}$ in width and $2.0-7.0 \mu \mathrm{m}$ in length) that are motile by gliding. Degenerative spherical cells are occasionally observed in ageing cultures in broth. Poly- $\beta$-hydroxybutyrate granules are stored as reserve material. Colonies are pale yellow, circular and convex with spreading margins and approximately $10-20 \mathrm{~mm}$ in diameter after 5 days incubation at $25{ }^{\circ} \mathrm{C}$ on MA. Flexirubintype pigments are absent ( $\mathrm{KOH}$ test negative). Carotenoid pigments are present with main absorption peaks at 480, 454 and $425 \mathrm{~nm}$. Growth occurs at $8-40{ }^{\circ} \mathrm{C}$, in the presence of $1-$ $10 \% \mathrm{NaCl}$ and at $\mathrm{pH} 7-9$. Optimum growth occurs at 30$35{ }^{\circ} \mathrm{C}$, with $3-4 \% \mathrm{NaCl}$ and at $\mathrm{pH}$ 8.0. Starch, DNA, casein, aesculin, gelatin and Tweens 40, 60 and 80 are hydrolysed, but chitin and Tween 20 are not. Oxidase and catalase activities are present. In the API 20NE strip, the reaction is positive for aesculin and gelatin hydrolysis, but negative for nitrate reduction, indole production, glucose fermentation, urease, arginine dihydrolase, $\beta$-galactosidase and assimilation of glucose, arabinose, mannose, mannitol, $\mathrm{N}$-acetylglucosamine, maltose, gluconate, caprate, adipate, malate, citrate and phenylacetate. In the API ZYM strip, alkaline phosphatase, C4 esterase, C8 lipase, C14 lipase, leucine arylamidase, valine arylamidase, cystine arylamidase, trypsin, $\alpha$-chymotrypsin, acid phosphatase and naphthol-AS-BI-phosphohydrolase activities are present, but $\alpha$-galactosidase, $\beta$-galactosidase, $\beta$-glucosidase, $\alpha$-glucosidase, $\beta$-glucuronidase, $N$-acetyl- $\beta$-glucosaminidase, $\alpha$-mannosidase and $\alpha$ fucosidase activities are absent. Resistant to gentamicin, kanamycin and streptomycin; sensitive to ampicillin, chloramphenicol, nalidixic acid, novobiocin, penicillin G, rifampicin and tetracycline. The major fatty acids $(>9 \%)$ are summed feature 3 (comprising $\mathrm{C}_{16: 1} \omega 7 c$ and/or iso- $\mathrm{C}_{15: 0}$ 2$\mathrm{OH})$, iso- $\mathrm{C}_{15: 0}$, iso- $\mathrm{C}_{16: 0} 3-\mathrm{OH}$, iso- $\mathrm{C}_{17: 0} 3-\mathrm{OH}$ and iso$\mathrm{C}_{15: 1}$. The predominant quinone is MK-6.

The type strain is $a 4^{\mathrm{T}}\left(=\right.$ BCRC $\left.17655^{\mathrm{T}}=\mathrm{LMG} 24004^{\mathrm{T}}\right)$, isolated from a sea anemone Aiptasia pulchella cultured in a laboratory in Taiwan. The DNA G $+\mathrm{C}$ content of the type strain is $35.0 \mathrm{~mol} \%$.

\section{Acknowledgements}

The original culture of sea anemone was provided by Dr M. Y. Leu in the National Museum of Marine Biology and Aquarium, Pingtung, 
Taiwan. The manuscript has been substantially enriched by the constructive suggestions of the referees.

\section{References}

Bernardet, J.-F. \& Nakagawa, Y. (2006). An introduction to the family Flavobacteriaceae. In The Prokaryotes, 3rd edn, vol. 7, pp. 455480. Edited by M. Dworkin, S. Falkow, E. Rosenberg, K.-H. Schleifer \& E. Stackebrandt. New York: Springer.

Bernardet, J.-F., Segers, P., Vancanneyt, M., Berthe, F., Kersters, K. \& Vandamme, P. (1996). Cutting a Gordian knot: emended classification and description of the genus Flavobacterium, emended description of the family Flavobacteriaceae, and proposal of Flavobacterium hydatis nom. nov. (basonym, Cytophaga aquatilis Strohl and Tait 1978). Int J Syst Bacteriol 46, 128-148.

Bernardet, J.-F., Nakagawa, Y. \& Holmes, B. (2002). Proposed minimal standards for describing new taxa of the family Flavobacteriaceae and emended description of the family. Int J Syst Evol Microbiol 52, 1049-1070.

Bowman, J. P. (2000). Description of Cellulophaga algicola sp. nov., isolated from the surfaces of Antarctic algae, and reclassification of Cytophaga uliginosa (ZoBell and Upham 1944) Reichenbach 1989 as Cellulophaga uliginosa comb. nov. Int J Syst Evol Microbiol 50, 1861-1868.

Chang, S. C., Wang, J. T., Vandamme, P., Hwang, J. H., Chang, P. S. \& Chen, W. M. (2004). Chitinimonas taiwanensis gen. nov., sp. nov., a novel chitinolytic bacterium isolated from a freshwater pond for shrimp culture. Syst Appl Microbiol 27, 43-49.

Chen, W. M., Laevens, S., Lee, T. M., Coenye, T., De Vos, P., Mergeay, M. \& Vandamme, P. (2001). Ralstonia taiwanensis sp. nov., isolated from root nodules of Mimosa species and sputum of a cystic fibrosis patient. Int J Syst Evol Microbiol 51, 1729-1735.

Choi, D. H., Kim, Y.-G., Hwang, C. Y., Yi, H., Chun, J. \& Cho, B. C. (2006). Tenacibaculum litoreum sp. nov., isolated from tidal flat sediment. Int J Syst Evol Microbiol 56, 635-640.

Chun, J., Lee, J.-H., Jung, Y., Kim, M., Kim, S., Kim, B. K. \& Lim, Y. W. (2007). EzTaxon: a web-based tool for the identification of prokaryotes based on $16 \mathrm{~S}$ ribosomal RNA gene sequence. Int J Syst Evol Microbiol 57, 2259-2261.

Collins, M. D., Hutson, R. A., Båverud, V. \& Falsen, E. (2000). Characterization of a Rothia-like organism from a mouse: description of Rothia nasimurium sp. nov. and reclassification of Stomatococcus mucilaginosus as Rothia mucilaginosa comb. nov. Int J Syst Evol Microbiol 50, 1247-1251.

Ezaki, T., Hashimoto, Y. \& Yabuuchi, E. (1989). Fluorometric deoxyribonucleic acid-deoxyribonucleic acid hybridization in microdilution wells as an alternative to membrane filter hybridization in which radioisotopes are used to determine genetic relatedness among bacterial strains. Int J Syst Bacteriol 39, 224-229.

Frette, L., Jørgensen, N. O. G., Irming, H. \& Kroer, N. (2004) Tenacibaculum skagerrakense sp. nov., a marine bacterium isolated from the pelagic zone in Skagerrak, Denmark. Int J Syst Evol Microbiol 54, 519-524.

GCG (1995). Wisconsin Package Version 8.1 Program Manual. Madison, WI: Genetics Computer Group.

Gerhardt, P., Murray, R. G. E., Wood, W. A. \& Krieg, N. R. (editors) (1994). Methods for General and Molecular Bacteriology. Washington, DC: American Society for Microbiology.

Hall, T. A. (1999). BioEdit: a user-friendly biological sequence alignment editor and analysis program for Windows 95/98/NT. Nucleic Acids Symp Ser 41, 95-98.
Hansen, G. H., Bergh, Ø., Michaelsen, J. \& Knappskog, D. (1992). Flexibacter ovolyticus sp. nov., a pathogen of eggs and larvae of Atlantic halibut, Hippoglossus hippoglossus L. Int J Syst Bacteriol 42, 451-458.

Jukes, T. H. \& Cantor, C. R. (1969). Evolution of protein molecules. In Mammalian Protein Metabolism, vol. 3, pp. 21-132. Edited by H. N. Munro. New York: Academic Press.

Jung, S.-Y., Oh, T.-K. \& Yoon, J.-H. (2006). Tenacibaculum aestuarii sp. nov., isolated from a tidal flat sediment in Korea. Int J Syst Evol Microbiol 56, 1577-1581.

Kluge, A. G. \& Farris, F. S. (1969). Quantitative phyletics and the evolution of anurans. Syst Zool 18, 1-32.

Kumar, S., Tamura, K. \& Nei, M. (2004). MEGA3: integrated software for molecular evolutionary genetics analysis and sequence alignment. Brief Bioinform 5, 150-163.

Lyman, J. \& Fleming, R. H. (1940). Composition of sea water. J Mar Res 3, 134-146.

MacFaddin, J. F. (2000). Biochemical Tests for the Identification of Medical Bacteria, 3rd edn. Baltimore: Lippincott Williams \& Wilkins.

Mesbah, M., Premachandran, U. \& Whitman, W. B. (1989). Precise measurement of the $\mathrm{G}+\mathrm{C}$ content of deoxyribonucleic acid by highperformance liquid chromatography. Int J Syst Bacteriol 39, 159-167.

Piñeiro-Vidal, M., Riaza, A. \& Santos, Y. (2008). Tenacibaculum discolor sp. nov. and Tenacibaculum gallaicum sp. nov., isolated from sole (Solea senegalensis) and turbot (Psetta maxima) culture systems. Int J Syst Evol Microbiol 58, 21-25.

Powers, E. M. (1995). Efficacy of the Ryu nonstaining $\mathrm{KOH}$ technique for rapidly determining gram reactions of food-borne and waterborne bacteria and yeasts. Appl Environ Microbiol 61, 3756-3758.

Reichenbach, H. (1992a). The order Cytophagales. In The Prokaryotes, 2nd edn, vol. 4, pp. 3631-3675. Edited by A. Balows, H. G. Trüper, M. Dworkin, W. Harder \& K. H. Schleifer. New York: Springer.

Reichenbach, H. (1992b). Flavobacteriaceae fam. nov. In Validation of the Publication of New Names and New Combinations Previously Effectively Published Outside the IJSB, List no. 41. Int J Syst Bacteriol 42, 327-328.

Saitou, N. \& Nei, M. (1987). The neighbor-joining method: a new method for reconstructing phylogenetic trees. Mol Biol Evol 4, 406-425.

Sasser, M. (1990). Identification of bacteria by gas chromatography of cellular fatty acids, MIDI Technical Note 101. Newark, DE: MIDI Inc.

Sheu, S. Y., Lin, K. Y., Chou, J. H., Chang, P. S., Arun, A. B., Young, C. C. \& Chen, W. M. (2007). Tenacibaculum litopenaei sp. nov., isolated from a shrimp mariculture pond. Int J Syst Evol Microbiol 57, 1148-1153.

Suzuki, M., Nakagawa, Y., Harayama, S. \& Yamamoto, S. (2001). Phylogenetic analysis and taxonomic study of marine Cytophaga-like bacteria: proposal for Tenacibaculum gen. nov. with Tenacibaculum maritimum comb. nov. and Tenacibaculum ovolyticum comb. nov., and description of Tenacibaculum mesophilum sp. nov. and Tenacibaculum amylolyticum sp. nov. Int J Syst Evol Microbiol 51, 1639-1652.

Wakabayashi, H., Hikida, M. \& Masumura, K. (1986). Flexibacter maritimus sp. nov., a pathogen of marine fishes. Int J Syst Bacteriol 36, 396-398.

Wang, J. T. \& Douglas, A. E. (1997). Nutrients, signals, and photosynthate release by symbiotic algae: the impact of taurine on the dinoflagellate alga Symbiodinium from the sea anemone Aiptasia pulchella. Plant Physiol 114, 631-636.

Wang, J. T. \& Douglas, A. E. (1998). Nitrogen recycling or nitrogen conservation in an alga-invertebrate symbiosis? J Exp Biol 201, 2445-2453. 
Wang, J. T. \& Douglas, A. E. (1999). Essential amino acid synthesis and nitrogen recycling in an alga-invertebrate symbiosis. Mar Biol 135, 219-222.
Yoon, J. H., Kang, S. J. \& Oh, T. K. (2005). Tenacibaculum lutimaris sp. nov., isolated from a tidal flat in the Yellow Sea, Korea. Int J Syst Evol Microbiol 55, 793-798. 